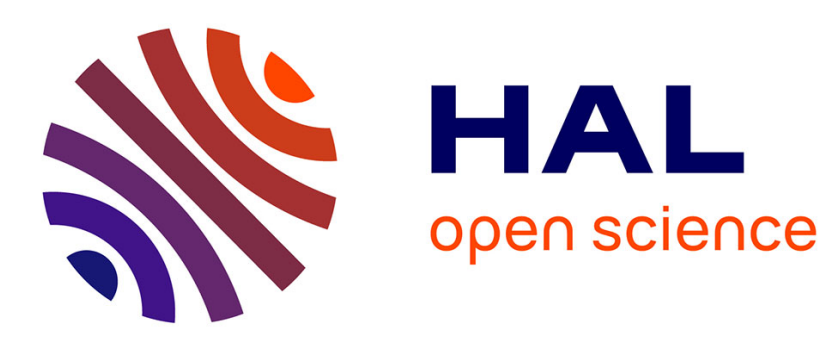

\title{
Numerical analysis of ventilation temperatures regulation by energy storage in phase change materials
}

\author{
J. Borderon, J. Virgone, R. Cantin
}

\section{To cite this version:}

J. Borderon, J. Virgone, R. Cantin. Numerical analysis of ventilation temperatures regulation by energy storage in phase change materials. ISES Solar World Congress, Aug 2011, Kassel, Germany. pp.10. hal-00763416

\author{
HAL Id: hal-00763416 \\ https://hal.science/hal-00763416
}

Submitted on 2 Jul 2014

HAL is a multi-disciplinary open access archive for the deposit and dissemination of scientific research documents, whether they are published or not. The documents may come from teaching and research institutions in France or abroad, or from public or private research centers.
L'archive ouverte pluridisciplinaire HAL, est destinée au dépôt et à la diffusion de documents scientifiques de niveau recherche, publiés ou non, émanant des établissements d'enseignement et de recherche français ou étrangers, des laboratoires publics ou privés. 


\title{
NUMERICAL ANALYSIS OF VENTILATION TEMPERATURES REGULATION BY ENERGY STORAGE IN PHASE CHANGE MATERIALS
}

\author{
Julien Borderon $^{1}$, Joseph Virgone ${ }^{2}$ and Richard Cantin ${ }^{1}$ \\ ${ }^{1}$ ENTPE, University of Lyon, LASH, Building and Civil Engineering Department, FRE CNRS 3237, France \\ ${ }^{2}$ University of Lyon, CETHIL, UMR 5008, INSA Lyon, University Lyon 1, France
}

\begin{abstract}
In order to cool a house using the freshness of the cold night air, Phase Change Materials (PCM) placed in an air heat exchanger coupled with a ventilation system have been investigated. The heat exchanger is composed of a number of units with horizontal PCM sheets contained in a box beam. Air is flown between the sheets from one side to the other and exchange heat with the material by convection. At night, fresh air is used to regenerate the PCM. To analyze the behavior of such a system in a retrofitted house with the climate of 3 different French cities, simulations in different configurations have been carried on. The TRNSYS software runs the model, coupled with Matlab for the model of the PCM / air heat exchanger. Results are expressed in terms of percentage of the time when the indoor temperature reaches each temperature and comparison between the different configurations.
\end{abstract}

\section{Introduction}

The building sector has the highest energy consumption in France (French Ministry of Ecology and Sustainable Development, 2007). Housing and tertiary buildings are responsible for approximately $46 \%$ of all energies and $19 \%$ of the total $\mathrm{CO} 2$ emissions. The thermal regulations restrict the energy consumption of new building and soon also the one of retrofitted buildings. The objectives are to save energy and keep high thermal comfort. Despite the fact that individual electric cooling system in housing are not encouraged in France, more and more installation have been noticed in the country. In retrofitting, the main solution is to reduce heat losses by addition of thermal insulation on external or in internal façade. The last solution often leads to thermal discomfort during summer period with the loss of the thermal inertia.

The use of Phase Change Materials (PCM) for building has been a subject of considerable interest in the last decade, for a review see Tyagi and Buddhi (2007) and Baetens et al. (2010). An interesting feature is that they can store latent heat energy, as well as sensible energy. As the temperature increases, the material changes phase from a solid to a liquid. As this physical reaction is endothermic, the PCM absorbs heat. Similarly, when the temperature decreases, the material changes phase from a liquid to a solid. As this reaction is exothermic, the PCM releases heat.

Among the different ways to include PCM in buildings, the use of thermal energy storage (TES) systems receives increasing interest. To allow high or low temperature thermal energy to be stored for later use, a heat or cool storage with PCM could be designed; Zhu et al (2009) reviewed the characteristics of the published systems. Koschenz and Lehmann (2004) developed a ceiling panel with PCM for application in lightweight and retrofitted buildings; they used aluminum fins to enhance the conduction through large PCM panel. The ventilation system of buildings could be associated to the TES system and therefore ventilation scenarios, with free cooling or free heating, could be designed. Lazaro (2009) had experimented two realscale prototypes of vertical PCM-air heat exchangers for free-cooling applications in buildings with macroencapsulated PCM. Takeda developed a ventilation system using thermal energy storage with granules containing phase change material which leads to cooling loads reduction up to $62 \%$ in the Kyoto climate (Takeda, 2004). Different systems with water instead of air as fluid vector have also been studied. Medrano (2009) used commercial water heat exchanger and filled them with PCM to realize a TES system. Another way to use PCM in building is to directly integrate panel in the walls or in the ceiling. Pasupathy and Velraj (2008) simulated and experimented simple and double layers of PCM in building roof with effective results 
and conclusion about the fusion temperature needed according to the climate. For a review on phase change material integrated in building walls, see Kuznik et al (2010).

Cabeza et al (2011) had reviewed the available materials potentially suitable for buildings use. In this study, paraffins with common characteristic have been used. Arkar et al. (2007a and 2007b) studied a low-energy building equipped with a ventilation system coupled with two latent heat thermal energy storage. They shew that in their case, for continental climate, a PCM with a melting temperature between 20 and $22^{\circ} \mathrm{C}$ is the best choice and with TRNSYS simulations, demonstrated that with their system equipped with $1230 \mathrm{~kg}$ of PCM, the summer thermal comfort is ensured for the $192 \mathrm{~m}^{2}$ house.

The object of this article is to evaluate the efficiency of a latent heat thermal energy storage system in the case of a retrofitted house with interior insulation to respect the future French standard 2012 for the U-value. Simulations have been carried on with 3 different weather files: Lyon, Nice and Trappes (close to Paris). First the buildings and the heat exchanger project are described with the method of simulation and the different studied configurations. Then the results are presented and analyzed with comparison between the different configurations and conclusion about the impact of the system on the summer comfort in the house.

\section{Method}

The type 56 of the TRNSYS software (Klein, 2005) has been used to model the building. This type has been connected with the air / PCM heat exchanger modeled in Matlab. The link is made via the type 155. The input parameter for the Type 56 from the type 155 is the air temperature for the ventilation.

\section{Model of the house}

The studied building is a French family house with a floor area of $100 \mathrm{~m}^{2}$ on one level with a garage, see figure 1 . The rooms are $2.5 \mathrm{~m}$ high, on a crawl space. There is a roof with a roof space. For the orientation, on the figure 1, the garage is on the west side. The modeling of the house is defined by two different thermal zones. The day zone is the living room and the night zone is the other rooms in the eastern part of the house. Schedules were used for lighting, and other internal gains. The house is for 4 people.

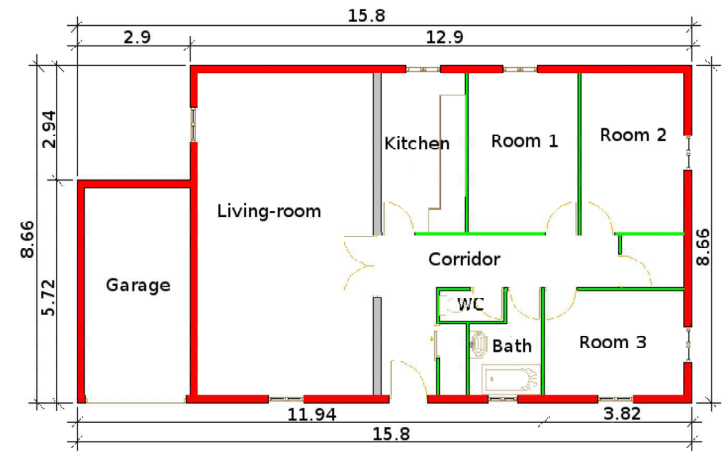

Figure 1: Modeled house (dimensions in m)

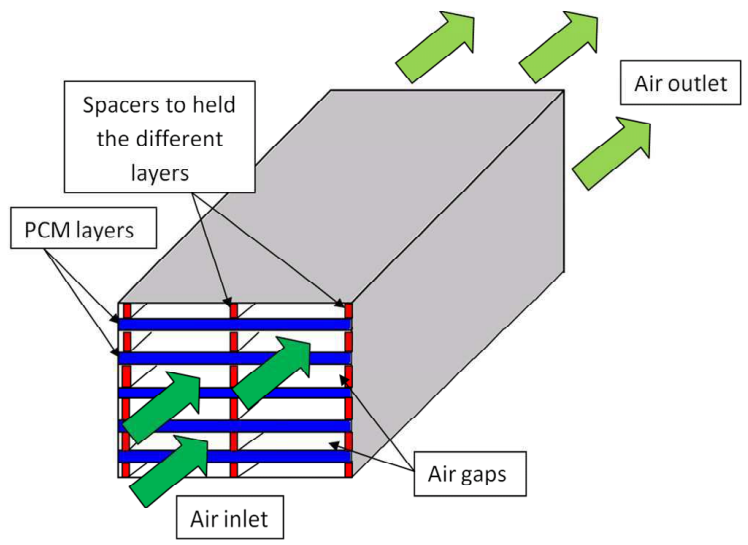

Figure 2: PCM / air heat exchanger

The ventilation of the building is set to 0.6 air change per hour (ach) when the specific system is not used. The composition of the walls, the roof and the floor, inside to outside are respectively the following:

- $\operatorname{gypsum}(0.01 \mathrm{~m})$ - polystyrene $(0.25 \mathrm{~m})$ - brick $(0.11 \mathrm{~m})$ - siding $(0.01 \mathrm{~m})$

- plaster board $(0.013 \mathrm{~m})$ - mineral wool $(0.40 \mathrm{~m})$

- concrete $(0.2 \mathrm{~m})$ - polystyrene $(0.1 \mathrm{~m})$

The thermal characteristics of the materials are in the table 1. 
Table 1: Thermophycal properties of the materials in the model of the house

\begin{tabular}{|c|c|c|c|}
\hline Material & $\boldsymbol{\lambda}(\mathbf{W} /(\mathbf{m} \cdot \mathbf{K}))$ & $\boldsymbol{\rho}\left(\mathbf{k g} / \mathbf{m}^{\mathbf{3}}\right)$ & $\mathbf{C p}(\mathbf{J} /(\mathbf{k g . K}))$ \\
\hline Gypsum & 0.32 & 1200 & 837 \\
\hline Polystyrene & 0.04 & 25 & 1380 \\
\hline Brick & 0.5 & 720 & 794 \\
\hline Siding & 1.15 & 1700 & 1000 \\
\hline Plaster board & 0.32 & 1200 & 837 \\
\hline Mineral wool & 0.03 & 35 & 1180 \\
\hline Concrete & 1.75 & 2300 & 920 \\
\hline
\end{tabular}

\section{Model of the PCM / air heat exchanger in Matlab}

The figure 2 presents a scheme of one unit of the heat exchanger. In this study: 1, 2 or 3 identical units will be tested. The thermal conductivity of the PCM is about $0.2 \mathrm{~W} /(\mathrm{m} . \mathrm{K})$ and to represent the phase change, the equivalent heat capacity method is used. The figure 3 represents the specific heat of the PCM according to the temperature. The total latent heat is $170 \mathrm{~J} / \mathrm{g}$. To consider different melting temperature in the study, the chosen method is to shift the curve is figure 3 , given for a peak at $23^{\circ} \mathrm{C}$, on the left to have the peak on $21^{\circ} \mathrm{C}$ or on the right to have the peak on $25^{\circ} \mathrm{C}$.

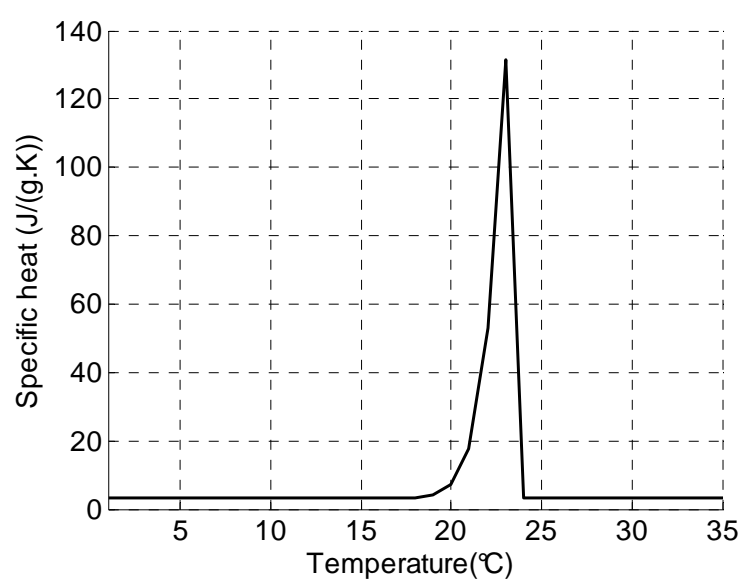

Figure 3: Modeled specific heat of the selected PCM

Each PCM layer has been modeled with a finite difference method in two dimensions, the thickness and the length of the layer. For each surface element, the energy conservation equation is:

$$
\lambda \times \Delta(T(x, y, t))=\rho_{P C M} \times C p_{P C M}(T) \times \frac{\partial T(x, y, t)}{\partial t}
$$

To solve the problem numerically, we have replaced the continuous information contained in the exact solution of the differential equation with discrete temperature values in space coordinate and time coordinate. The spatial discretization is second-order finite-differences scheme. The index $n$ is for the time and the index $i$ is for the space coordinate. We have $m$ node in the $x$ direction and $w$ node in the $y$ direction. The node are numbered from 1 to $n=w . m$. The time discretization uses a first-order backward difference expression. The final finite difference equation with the PCM specific heat at time $\mathrm{n} C p_{i}^{n}$ is:

$$
\rho_{i} \times C p_{i}^{n} \times \frac{T_{i}^{n+1}-T_{i}^{n}}{\Delta t}=-\lambda \times\left(\frac{T_{i-1}^{n+1}-2 \times T_{i}^{n+1}+T_{i+1}^{n+1}}{\Delta x^{2}}+\frac{T_{i-m}^{n+1}-2 \times T_{i}^{n+1}+T_{i+m}^{n+1}}{\Delta y^{2}}\right)
$$

For each time step, for each node, the equivalent specific heat of the PCM is calculated using representative equations of the curve in the figure 3. The heat transfer coefficients are calculated for laminar or turbulent 
flow with calculation based on the Nusselt number, (Borderon, 2010). For laminar flow, the Nusselt number is calculated with the Gratz-Nusselt relation adapted to this geometry (Shah and London, 1978):

$$
N u=7.541+\frac{0.0235 \cdot \operatorname{Re} \cdot \operatorname{Pr} \cdot d h}{L}
$$

For turbulent flow, the Nusselt number is calculated with the Colburn correlation in first approximation:

$$
N u=0.023 \cdot \operatorname{Re}^{0.8} \cdot \operatorname{Pr}^{1 / 3}
$$

The problem is solved with a matrix equation, with the implicit finite difference method:

$$
T^{k+1}=\left(I d-\Delta t \times C^{-1} \times A\right)^{-1} \times T^{k}+\Delta t \times\left(I d-\Delta t \times C^{-1} \times A\right)^{-1} \times C^{-1} \times B \times U^{k+1}
$$

Where:

- $\quad T$ is the vector is the temperatures of each node for the time step $\mathrm{i}$

- $\quad I d$ is the matrix identity

- $C$ is the matrix which contains the heat capacity of each node, calculated at each iteration

- $A$ is the matrix with the thermal conductance

- $B U$ is the matrix with the exterior solicitation.

The melting degree of the PCM and the cooling power developed by the heat exchanger are also calculated.

\section{Climate}

Simulations have been carried on with 3 different weather files: Lyon, Nice and Trappes. These climates present some differences as the daily variation of the temperature and the average temperature or the night temperature. In the bibliography, Arkar and Medved (2007) have interesting results with their PCM system with a continental climate. Its characteristic is an average temperature of $25^{\circ} \mathrm{C}$ and daily variations between $17.5^{\circ} \mathrm{C}$ and $32.5^{\circ} \mathrm{C}$. In France, in the 3 weather files considerated, the daily amplitudes are less considerable and the average temperature on a day is inferior most of the time. The figure 4 presents the number of days between June and September (122 days) for each daily average temperature. Nice is warmest climate with 85 days with an average temperature superior to $20^{\circ} \mathrm{C} .23{ }^{\circ} \mathrm{C}$ is the more representative average temperature with 19 days. Lyon has 38 days with an average temperature superior to $20^{\circ} \mathrm{C}$ and Trappes is the coldest climate with 21 days with an average temperature superior to $20^{\circ} \mathrm{C}$.

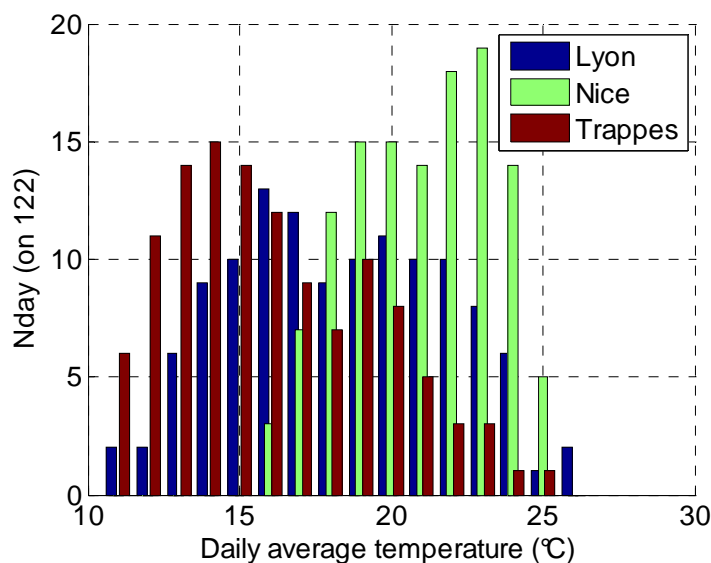

Figure 4: Statistics on the value of the daily average outdoor temperature for June, July, August and September

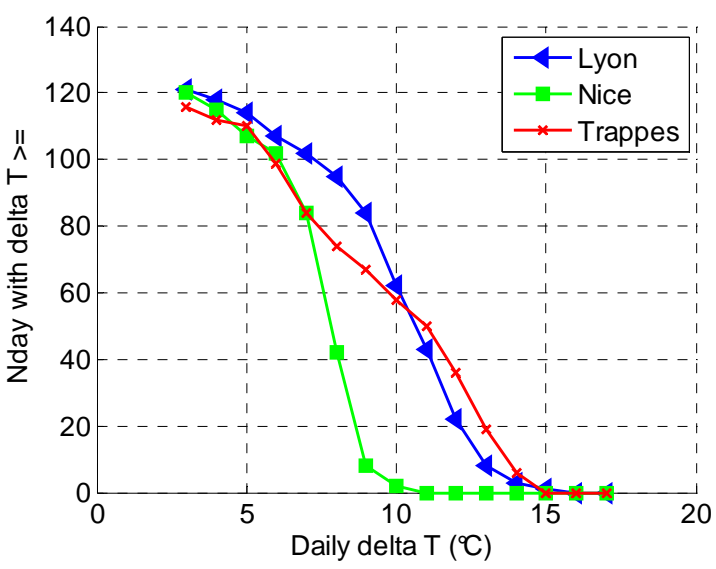

Figure 5: Statistics on the minimum value of the daily outdoor temperature amplitude for June, July, August and September

Concerning the daily amplitude of the temperature in the 3 cities, they are far from the $15^{\circ} \mathrm{C}$ in the previous named study. The figure 5 represents the numbers of days in the period from June to September when the daily amplitude of the temperature reaches each temperature level. It appears that for Nice, $94 \%$ of the days 
have a daily amplitude for the temperature inferior to $9^{\circ} \mathrm{C}$ and $66 \%$ of the days inferior to $8^{\circ} \mathrm{C}$. For Lyon, the amplitudes are more considerable, $50 \%$ of the days have daily amplitudes superior or equal to $10^{\circ} \mathrm{C}$. It's the same for Trappes.

These considerations on the climate are important to choose the melting temperature of the PCM and the ratio between thickness of the PCM layers and exchange surfaces. With small daily amplitude of the exterior temperature, the regeneration of the PCM at night will be more difficult and the cooling power of the heat exchanger will be smaller.

\section{Sizing of the PCM units}

To choose the dimensions of the PCM units, several parametric simulations have been realized with sinusoidal inlet temperature. The average temperature is $24^{\circ} \mathrm{C}$, the maximum is $29^{\circ} \mathrm{C}$ and the minimum $19^{\circ} \mathrm{C}$, the period is $24 \mathrm{~h}$. Finally: one unit is composed of 16 PCM sheets of $1.2 \mathrm{~m}$ large, $1.2 \mathrm{~m}$ long and a thickness of $0.015 \mathrm{~m}$. The air gap between 2 PCM layers is $0.01 \mathrm{~m}$ thick. So the dimensions of the unit are $1.2 \times 1.2 \times 0.4 \mathrm{~m}$, for a volume of $0.58 \mathrm{~m}^{3}$ and with the PCM density equal to $1000 \mathrm{~kg} / \mathrm{m}^{3}$, a mass of $350 \mathrm{~kg}$. For 2 of these units with a melting temperature of $23^{\circ} \mathrm{C}$, the power of the PCM / air heat exchanger is presented on the figure 6.

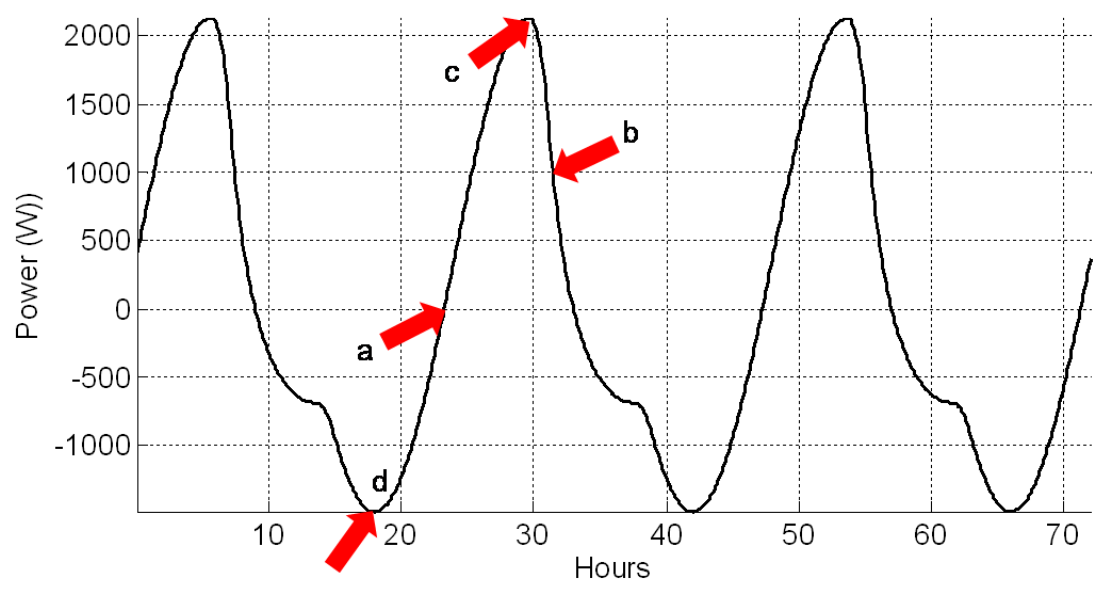

Figure 6: Power of the PCM/air heat exchanger

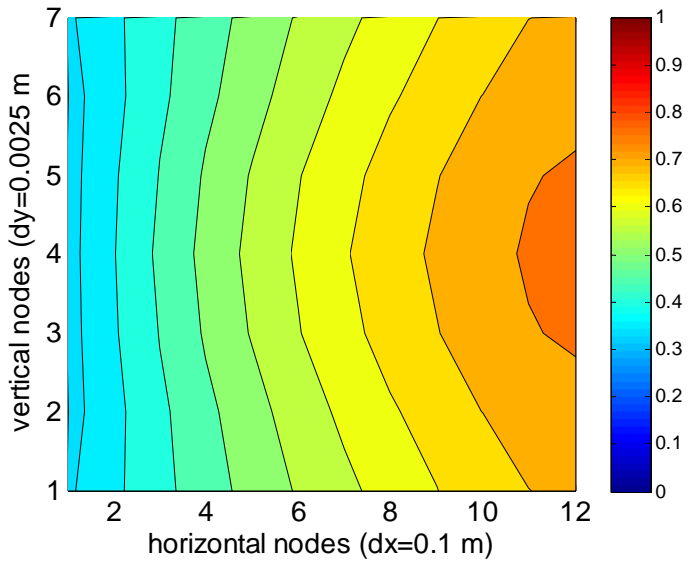

Figure 7: Melting degree of the PCM, point a

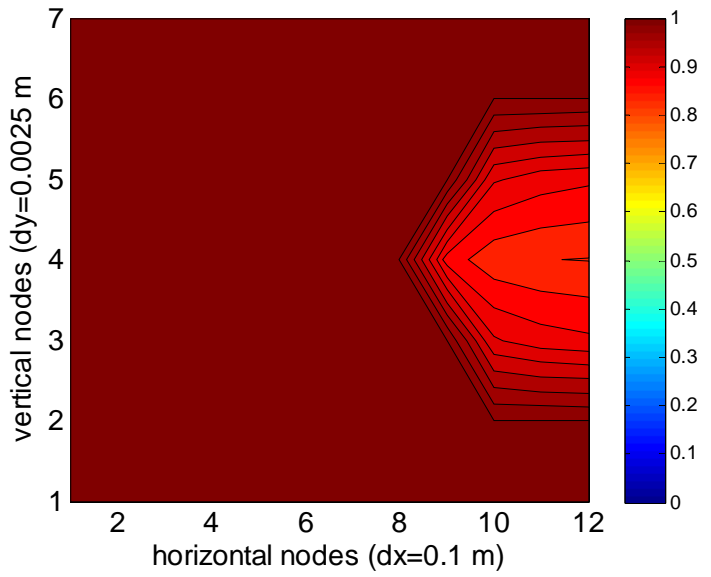

Figure 8: Melting degree of the PCM, point $b$ 


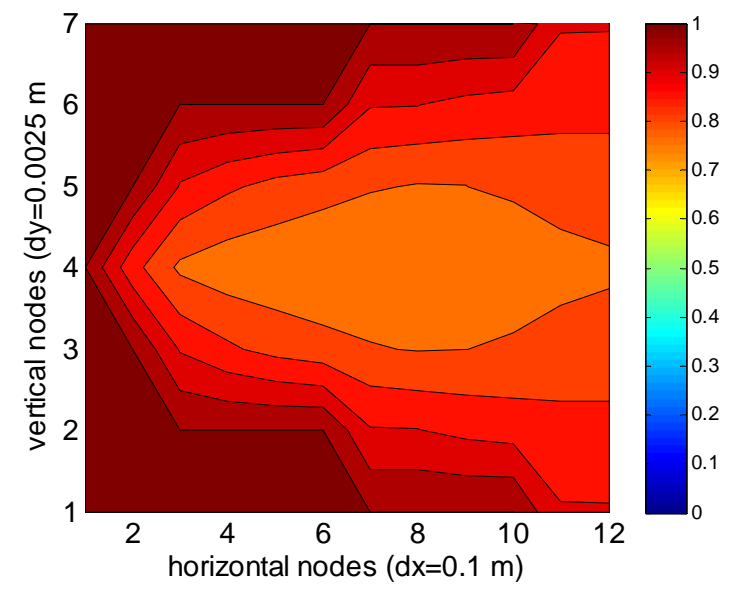

Figure 9: Melting degree of the PCM, point c

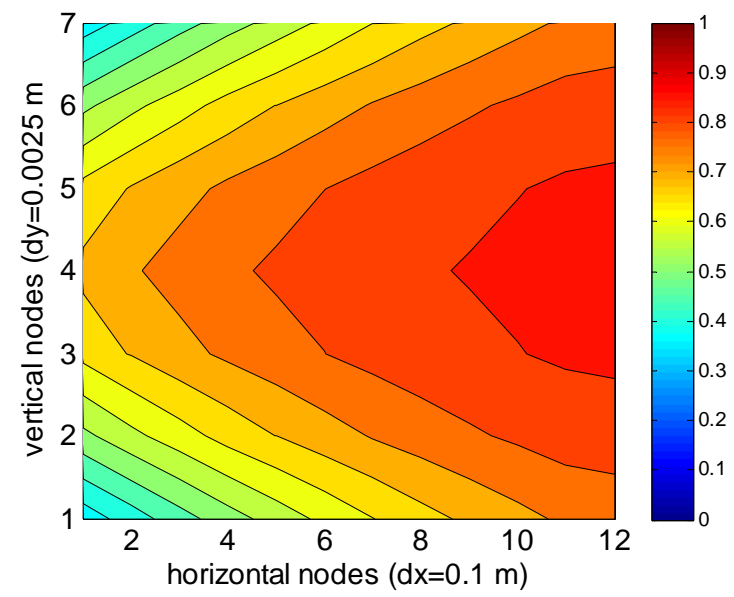

Figure 10: Melting degree of the PCM, point d

The letter a, b, c and d refer to the time value for the figure 7, 8, 9 and 10. These figures show the melting degree in a PCM layer. 0 is the value when all the PCM is solid, whereas 1 is the value when all the PCM is in liquid phase. On the figure 7, all the PCM is not solid as it would be in the optimum case. At the end of the exchanger, in the middle, the PCM is still $70 \%$ liquid. On the figure 10, at the maximum power for the heat exchange between air and PCM, the leading edge solidify well but at the other end, the PCM is still more liquid than solid. On the figure 9, at the opposite maximum, the leading edge for the air is totally liquid but there are still nodes at the middle which are only $70 \%$ liquid thanks to low conductivity of the material. On the figure 8, nearly all the PCM is melted.

\section{Results and analysis}

\section{Tested configurations}

The first configuration for each climate is the reference. It's the case with the house described previously with the same air change rate planned in the cases with PCM units, 6 ach. The configuration 7 is the reference case for the configuration 6 with PCM, for these two configurations, the air change rate is 3 ach. The table 2 presents the configurations with the parameters: melting temperature, number of PCM units and air flow rates.

Table 2: Tested configurations of the air/PCM heat exchanger

\begin{tabular}{|c|c|c|c|}
\hline Configuration & Melting temperature & Number of PCM units & Air flow $\left(\mathbf{m}^{\mathbf{3}} / \mathbf{h}\right)$ \\
\hline 1 & - & 0 & 1500 \\
\hline 2 & 23 & 3 & 1500 \\
\hline 3 & 23 & 2 & 1500 \\
\hline 4 & 21 & 2 & 1500 \\
\hline 5 & 25 & 2 & 1500 \\
\hline 6 & 21 & 1 & 750 \\
\hline 7 & - & 0 & 750 \\
\hline
\end{tabular}

For the 3 different weather files, the results on the indoor air temperature have been compiled in numbers of hours when the indoor temperature is at least equal to the considered air temperature. The different configurations have been represented on the figure 11 for Lyon, 12 for Nice and 13 for Trappes. The studied period began the $1^{\text {st }}$ of June and ended the $30^{\text {th }}$ of September. 1 PCM units represents a mass of $350 \mathrm{~kg}, 2$ units $700 \mathrm{~kg}$ and 3 units $1050 \mathrm{~kg}$. 


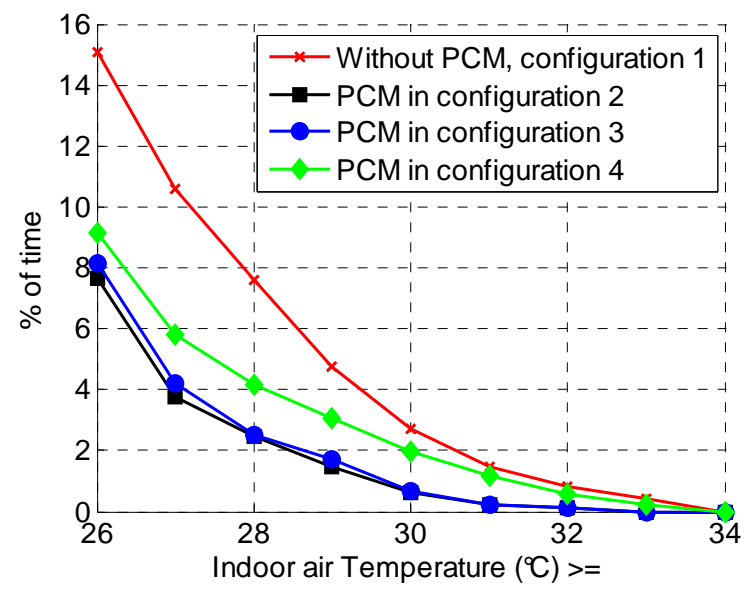

Figure 11: Percentage of time between June $1^{\text {st }}$ and September $30^{\text {th }}$ when the indoor temperature is at least equal to a certain value for the different configurations in Lyon

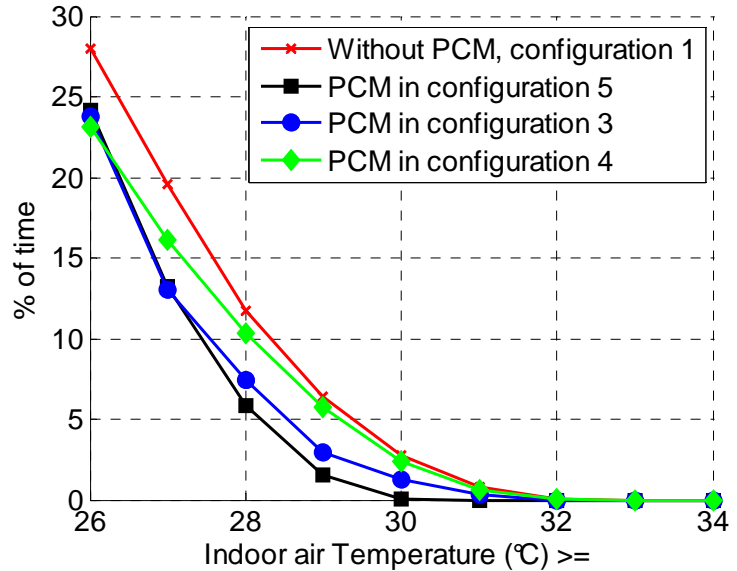

Figure 12: Percentage of time between June $1^{\text {st }}$ and September $30^{\text {th }}$ when the indoor temperature is at least equal to a certain value for the different configurations in Nice

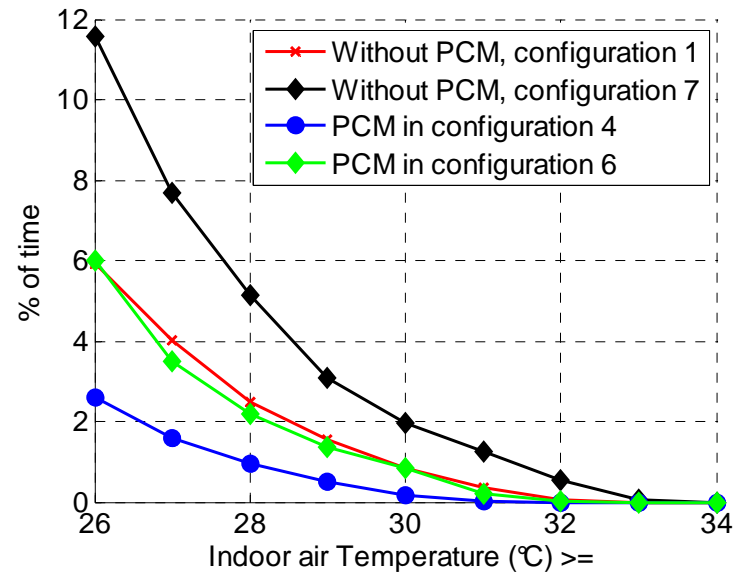

Figure 13: Percentage of time between June $1^{\text {st }}$ and September $30^{\text {th }}$ when the indoor temperature is at least equal to a certain value for the different configurations in Trappes

\section{Discussions}

The best performance of the PCM is for the climate of Lyon. The configuration 2 and 3 give quite similar results, so to add a third unit without changing the air change rate per hour is not advantageous in this case. The melting temperature of $23^{\circ} \mathrm{C}$ has better results than the melting temperature of $21^{\circ} \mathrm{C}$. There are 690 time steps (one time step is 5 minutes) with the indoor air temperature superior or equal to $30^{\circ} \mathrm{C}$ with the melting temperature of the PCM equal to $21^{\circ} \mathrm{C}$ and 220 time steps for the one with $23^{\circ} \mathrm{C}$. On the studied period, in reference case with a high ventilation rate: 6 air changes per hour, the interior temperature is higher than $26^{\circ} \mathrm{C}$ in $15 \%$ of the time, with a normal ventilation rate: 0.6 air change per hour it's $49 \%$ of the time. The over-ventilation with exterior air is efficient in itself to decrease significantly the temperature in the building. With the PCM, the percentage of time with the indoor temperature superior to $26^{\circ} \mathrm{C}$ is reduced to less than $7.6 \%$, approximately 200 hours.

For the climate of Nice, the most disadvantageous for PCM because for low daily amplitude of the exterior air temperature, 3 different melting temperatures have been tested, 21,23 and $25^{\circ} \mathrm{C}$. The scenario with the melting temperature of $21^{\circ} \mathrm{C}$ gives bad results, especially the hottest days. This is clearly because the PCM does not solidify enough or does not solidify at all at night. The best scenario is the one with the melting temperature of $25^{\circ} \mathrm{C}$. His behavior becomes more interesting for the hottest days, allowing a large part of the 
PCM to regenerate at night. On the studied period, in reference case with a high ventilation rate: 6 air changes per hour, the interior temperature is higher than $26^{\circ} \mathrm{C}$ in $28 \%$ of the time, with a normal ventilation rate: 0.6 air change per hour it's $58 \%$ of the time. With the PCM, the percentage of time with the indoor temperature superior to $26^{\circ} \mathrm{C}$ is reduced to $23 \%$ in the best scenario. The temperature in the building exceed $30^{\circ} \mathrm{C}$ during 81 time steps in the scenario with only over-ventilation, reduced to 18 time steps in the best scenario with PCM. That is respectively 18 hours and 1.5 hours.

At last, in the climate of Trappes, the PCM with a melting temperature of $21^{\circ} \mathrm{C}$ has been tested in a scenario with one PCM unit and 3 air changes per hour for the ventilation and in a scenario with two PCM units and 6 air changes per hour. It's interesting to notice that the case with one PCM units and a ventilation rate of 3 air changes per hour has approximately the same results in terms of indoor air temperature than the case no PCM but an over-ventilation of 6 ach. On the studied period, in reference case with a high ventilation rate: 6 ach, the interior temperature is higher than $26^{\circ} \mathrm{C}$ in $11.6 \%$ of the time, with a normal ventilation rate: 0.6 ach it's $29 \%$ of the time and with 3 ach it's $6 \%$ of the time. In the case with 2 PCM units this percentage is reduced to $2.6 \%$ and in the same scenario, the indoor temperature reaches $30^{\circ} \mathrm{C}$ only $0.18 \%$ of the time (63 time steps, approximately 1 hour).

The figure 14 illustrates the air temperatures in the building, outdoor and the temperature at the outlet of the heat exchanger for 3 consecutive warm days of July in Lyon. The figure 15 presents the power developed by the heat exchanger for these same days.

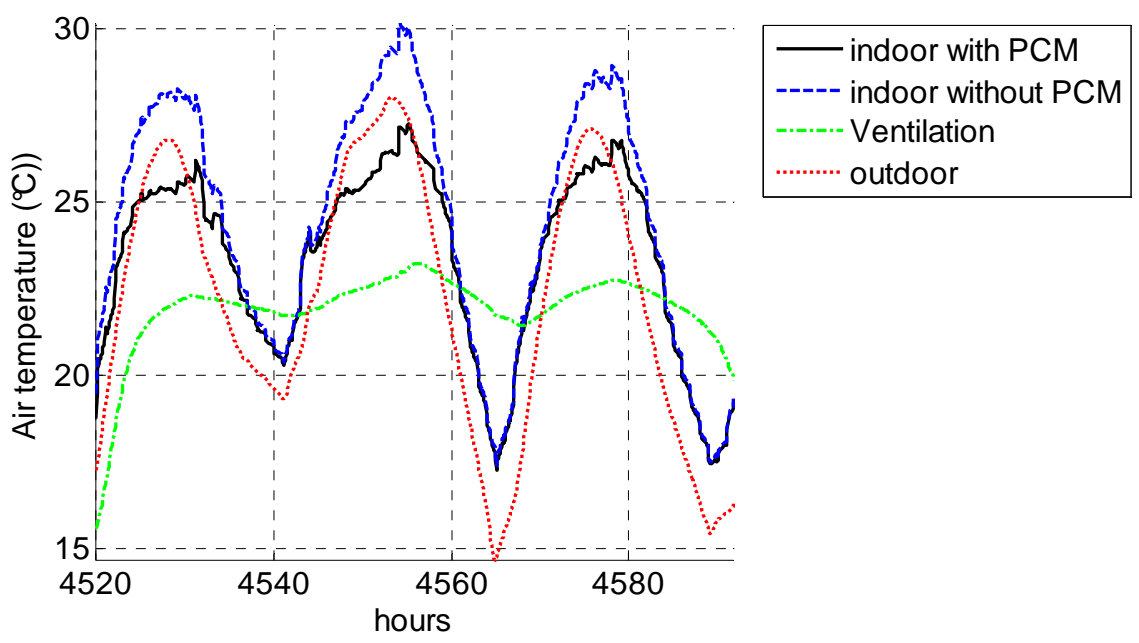

Figure 14: Air temperature for 3 days in July for the configuration 2 in Lyon

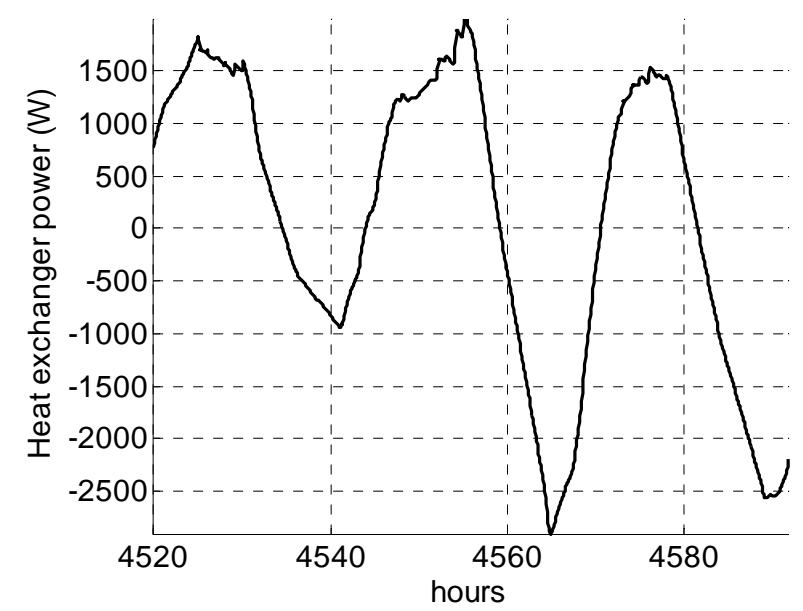

Figure 15: Power of the PCM / air heat exchanger for 3 days in July for the configuration 2 in Lyon 
During these 3 days, the exterior temperature reaches $28^{\circ} \mathrm{C}$ in the day and has a minimum of $19.5^{\circ} \mathrm{C}$ the first night and $15^{\circ} \mathrm{C}$ the second night. There is a situation of thermal discomfort as the temperature in the house reaches $30^{\circ} \mathrm{C}$ the second day, even with an over-ventilation of 6 ach. The PCM allows to reduce the indoor air temperature of $3^{\circ} \mathrm{C}$. The temperature at the outlet of the PCM / air heat exchanger is around the melting temperature of the PCM as expected. The cooling power of the heat exchanger is maximum when the outdoor temperature is $30^{\circ} \mathrm{C}$ : it's $1900 \mathrm{~W}$. The power at night, to regenerate the PCM is maximum when the outdoor temperature is miminum, it's $3000 \mathrm{~W}$. The first night, as the night air temperature only decrease to $19.5^{\circ} \mathrm{C}$, the power is less than $1000 \mathrm{~W}$.

In all these tested cases, the thermal comfort is not guaranteed $100 \%$ of the time for the 3 climates. But the over-ventilation and the PCM / air heat exchanger in the best configurations gives promising results. As expected, the climate with the highest daily amplitude of the temperature is the most compatible with PCM. With the climate of Trappes, the thermal comfort in the building is reached with 2 PCM units, $97.4 \%$ of the time during the summer. With the climate of Lyon, the system allows to limit seriously the thermal discomfort during summer. In Nice, the results are less impressive, in a large part because of problem of solidification of the PCM at night. The small daily amplitude of the temperature in this climate and the hot temperatures forces to use a PCM with a melting temperature of $25^{\circ} \mathrm{C}$.

The electric consumption of the system is the consumption of the fans, in a first approximation, with an hypothesis of a power of $0.25 \mathrm{~W} /\left(\mathrm{m}^{3} / \mathrm{h}\right)$, the energy demand of the system is summarized in the table 3 . This hypothesis is the one used in the French regulation.

Table 3: energy consumption of the fans in first approximation

\begin{tabular}{|c|c|c|}
\hline Air flow rates & Power for the fans & $\begin{array}{c}\text { Energy for the house for June, } \\
\text { July, August and September }\end{array}$ \\
\hline $750 \mathrm{~m}^{3} / \mathrm{h}$ & $187.5 \mathrm{~W}$ & $5.5 \mathrm{kWh} /\left(\mathrm{m}^{2} .(4 \mathrm{months})\right)$ \\
\hline $1500 \mathrm{~m}^{3} / \mathrm{h}$ & $375 \mathrm{~W}$ & $11 \mathrm{kWh} /\left(\mathrm{m}^{2} .(4 \mathrm{months})\right)$ \\
\hline
\end{tabular}

\section{Conclusion}

An insulated French single house has been modeled and several simulations in different configurations with a PCM / air heat exchanger have been performed in 3 different climates. The results show the main impact of the daily amplitude of the exterior air temperature on the system. In most studied cases the solidification of the PCM at night is only partial. That leads to a non-optimal use of the PCM system. A solution could be to control the air flow rates through the heat exchanger and to increase it when the night temperature is less fresh. However the air flow rate through the system is limited by the pressure drop and the sizing of the fans.

The thermal comfort in the house with the PCM system coupled to an over-ventilation is significantly improved in the 3 climates. In Lyon and Trappes, the number of hours in the summer with overheating problems is reduced to few percents. If $26^{\circ} \mathrm{C}$ is considered as the limit, then it's $2.6 \%$ for Trappes and less than $8 \%$ for Lyon. $700 \mathrm{~kg}$ of PCM have been used in the PCM / air heat exchanger to reach these results.

\section{References}

Arkar, C. and Medved, S, 2007. Free cooling of a building using PCM heat storage integrated into the ventilation system. Solar Energy, 81(9):1078-1087.

Arkar, C., Vidrih, B., and Medved, S, 2007. Efficiency of free cooling using latent heat storage integrated into the ventilation system of a low energy building. International Journal of Refrigeration, 30(1):134-143.

Baetens, R., Jelle, B. P., Gustavsen, A, 2010. Phase change materials for building applications : a state of the art review. energy and Buildings 42, 1361-1368. 
Borderon, J., Virgone, J. and Cantin, R., 2010. Etude paramétrique d'un échangeur thermique air/matériaux à changement de phase pour le rafraichissement des bâtiments. In proceedings, conference SFT 2010 : 967972.

Cabeza, L.F., Castell, A., Barreneche, C., de Gracia, A., Fernandez, A.I., 2011. Materials used as PCM in thermal energy storage in buildings: A review. Renewable and Sustainable energy Reviews. 15, 1675-1695.

French Ministry of Ecology and Sustainable Development, 2007. Grenelle de l'environnement, rapport général. Report.

Hed, G., Bellander, R., 2006. Mathematical modelling of PCM air heat exchanger. Energy and Buildings 38, 82-89.

Klein, S.A. et al., 2005. TRNSYS 16 Manual.

Koschenz, M., Lehmann B., 2004. Development of a thermally activated ceiling panel with PCM for application in lightweight and retrofitted buildings. Energy and Buildings 36: 567-578.

Kuznik, F., David, D., Johannes, K., Roux, J.J., 2011. a review on phase change materials integrated in building walls. Renewable and Sustainable energy Reviews. 15, 379-391.

Lazaro, A., Dolado, P., Marin, J.M., Zalba, B., 2009. PCM-air heat exchangers for free-cooling applications in buildings: Experimental results of two real-scale prototypes. Energy Conversion and Management 50(3): 439-443

Medrano, M. Yilmaz, M. O., Nogues, M., Martorell, I., Roca, J., Cabeza, L. F., 2009. experimental evaluation of commercial heat exchangers for use as PCM thermal storage systems. Applied Energy 86, 2047-2055.

Pasupathy, A., Velraj, R., 2008. effect of double layer phase change material in building roof for year round thermal management. Energy and Building 40, 193-203.

Shah, R.K., London, A.L., 1978. Laminar flow forced convection in ducts, Supplement 1 at Advances in Heat Transfer, Academic Press, New York.

Takeda, S., Nagano, K., Mochida, T., Shimakura, K., 2004. Development of a ventilation system utilizing thermal energy storage for granules containing phase change material. Solar Energy 77, 329-338.

Tyagi, V.V., Buddhi, D., 2007. PCM thermal storage in buildings: A state of art. Renewable and Sustainable Energy Reviews 11: 1146-1166.

Zhu, N., Ma, Z., Wang, S.,2009. Dynamic characteristics and energy performance of buildings using phase change materials : a review. Energy Conversion and Management 50: 3169-3181. 